\title{
Efektywne wykorzystanie surowców energetycznych w Polsce na tle krajów Unii Europejskiej
}

Emilia Łysik Studentka, Uniwersytet Łódzki, Wydział Ekonomiczno-Socjologiczny, Katedra Gospodarki Światowej i Integracji Europejskiej

\section{Wstęp}

W pracy podjęto próbę zaprezentowania efektywnego wykorzystania zasobów energetycznych. Szczegółowo wyjaśniono pojęcia istotne do zrozumienia zakresu pracy oraz przedstawiono dokumenty $\mathrm{w}$ zakresie energetyki i jej efektywności. Skupiono się na przedstawieniu sytuacji zużycia surowców energetycznych w Polsce i porównaniu z Unią Europejską. Opisane zostały również działania w kierunku poprawy efektywności energetycznej. Wspomniano także o zrównoważonej energetyce $\mathrm{i}$ istocie bezpieczeństwa energetycznego.

\section{Polityka efektywności energetycznej}

$\mathrm{Na}$ całym świecie energia jest istotną częścią naszego życia, która w dużej mierze ułatwia nam funkcjonowanie każdego dnia, poprzez wykorzystywanie urządzeń opartych na elektryczności. Niestety znaczna część wytwarzanej energii jest marnotrawiona, a jej wytwarzanie z niektórych źródeł w dużej mierze przyczynia się do zanieczyszczenia środowiska. Ze względu na ilość wytwarzanych zanieczyszczeń wymagania środowiskowe rosną. Dlatego też coraz większy nacisk kładzie się na poprawę efektywności energetycznej. Wykorzystanie surowców energetycz- 
nych i ich efektywność jest działem, które należy do szeroko rozumianej gospodarki paliwowo-energetycznej. Gospodarka ta obejmuje zjawiska i procesy związane z pozyskiwaniem i wykorzystaniem nośników energii, a także procesy przetwarzania nośników energii na inne nośniki oraz procesy końcowego zużycia paliw i energii ${ }^{1}$.

Gospodarka energetyczna zapewnia towary i usługi poprzez produkcję i handel, obejmuje budowę i eksploatację infrastruktury technicznej dla pozyskiwania, przewozu, składowania, i użytkowania różnych form energii. Celem gospodarki energetycznej jest zapewnienie ciągłości dostaw energii oraz minimalizacja kosztów energii²

Gospodarowanie zasobami od zawsze było ważnym tematem z działu sektora energetycznego ze względu na dostępność energii i jej kosztów. W ostatniej dekadzie w skali globalnej istotne znaczenie ma problem wyczerpywania się zasobów dostępnych przy umiarkowanych kosztach, jak również importowanie surowców gazu i ropy z innych krajów ${ }^{3}$.

Efektywność energetyczna jest jednym $\mathrm{z}$ najważniejszych obszarów polityki energetyczno-klimatycznej Unii Europejskiej. Pakiet klimatyczno-energetyczny do 2020 roku określa trzy najważniejsze cele, które to państwa członkowskie Unii Europejskiej zobowiązały się do ich zrealizowania. Pierwszym celem jest zwiększenie efektywności energetycznej w roku 2020 o 20\% w porównaniu do roku 2005. Drugi cel zakłada wzrost zużycia energii ze źródeł odnawialnych do $20 \%$, dla Polski do 15\%. Trzecim zadaniem pakietu jest skupienie się na redukcji emisji dwutlenku węgla o $20 \%$ do roku 2020 , w porównaniu z rokiem 1990. Przedstawione cele są jednocześnie głównymi założeniami strategii „Europa 2020"4.

Polityka efektywności energetycznej w Polsce jest regulowana poprzez dokumenty, do najważniejszych z nich należą:

- Ustawa o efektywności energetycznej ${ }^{5}$,

- Polityka Energetyczna Polski do 2030 roku$^{6}$,

- Krajowe Plany Działań (KPD) dotyczący efektywności energetycznej.

1 Główny Urząd Statystyczny, Gospodarka paliwowo-energetyczna w latach 2013/2014.

2 B. Gerhard, M. Tomaszewski, Polityka energetyczna i bezpieczeństwo energetyczne, Wydawnictwo Nowa, Opole, 2009, s. 35-36.

3 Ibidem, s. 21.

4 Pakiet klimatyczno-energetyczny do 2020 roku, ec.europa.eu/clima/policies/strategies/2020/ index_pl.htm [dostęp online: 15.05.2016].

5 Ministerstwo Gospodarki, Ustawa z dnia 15 kwietnia 2011 o efektywności energetycznej.

6 Ministerstwo Gospodarki, Polityka Energetyczna Polski do 2030 roku, Warszawa, 10 listopada 2009.

7 Ministerstwo Gospodarki, Krajowy Plan Działań (KPD) dotyczący efektywności energetycznej dla Polski, Warszawa, 20 października 2014. 
Ustawa o efektywności energetycznej definiuje efektywność energetyczną jako stosunek wielkości otrzymanego efektu danego obiektu, urządzenia technicznego lub instalacji do ilości energii zużytej przez ten obiekt, instalację lub obiekt techniczny niezbędny do otrzymania tego efektu8.

W Krajowym Planie Działań został zamieszczony opis środków mających na celu poprawę efektywności energetycznej. Przykłady takich środków zostały opisane poniżej w dziale Działania mające na celu poprawę efektywności energetycznej.

Polityka energetyczna UE nie dotyczy wyłącznie sektora energii, ale również ochrony środowiska, podatków, handlu i konkurencji. Ma na celu budowę wspólnego rynku energii, zapewnienie bezpieczeństwa dostaw energii oraz ochronę środowiska. W wyniku wdrożenia Polityki Energetycznej Polski do roku 2030 głównym celem jest utrzymanie zerowego zapotrzebowania na energię pierwotną oraz zmniejszenie energochłonności polskiej gospodarki. W dużej mierze przyczyni się to do bezpieczeństwa energetycznego, redukcji emisji zanieczyszczeń do wzrostu innowacyjności, a w końcu do oszczędności energii co poprawi efektywność ekonomiczną i energetycznąa

\section{Surowce energetyczne i ich zużycie w Polsce na tle krajów Unii Europejskiej}

Istotny wpływ na załamanie gospodarki światowej miał rynek surowców energetycznych. Chodzi głównie o rynek ropy naftowej, gazu ziemnego, węgla brunatnego i kamiennego. Każdy kraj korzysta z dostępnych źródeł energii w zależności od zapotrzebowania na nią i rozwoju gospodarczego. Polska jest krajem bogatym w zasoby węgla brunatnego i węgla kamiennego, natomiast ropa naftowa i gaz ziemny są importowane w dużej mierze z Rosji w celu zaspokojenia potrzeb krajowych ${ }^{10}$.

Istotne w kwestii efektywności energetycznej jest wyjaśnienie, że pojęcie energii kryje w sobie sumę energii pierwotnej i finalnej. Dla jasnego zrozumienia różnic pomiędzy tymi pojęciami zostały one dokładniej wyjaśnione.

Energia pierwotna jest energią czerpaną bezpośrednio z przyrody, zarówno z zasobów odnawialnych, jak i nieodnawialnych, która nie była jeszcze przetworzona. Przykłady energii pierwotnej zostały zaprezentowane w poniższej Tabeli $1^{11}$.

\footnotetext{
8 Ministerstwo Gospodarki, Ustawa z dnia 15 kwietnia....

9 Ministerstwo Gospodarki, Polityka energetyczna....

10 M. Brzóska, Gospodarka surowcami energetycznymi na świecie i w Polsce w kontekście dyrektyw unijnych, [w] P. Kwiatkiewicz (red), Bezpieczeństwo energetyczne-surowce kopalne vs alternatywne źródła energii, Wydawnictwo Wyższej Szkoły Bezpieczeństwa, Poznań, 2013, s. 291-293.

11 Główny Urząd Statystyczny, Gospodarka paliwowo....
} 


\begin{tabular}{|l|l|}
\hline \multicolumn{2}{|c|}{ Energia pierwotna } \\
\hline Zasoby odnawialne & \multirow{2}{*}{ Zasoby nieodnawialne } \\
\hline Energia fal morskich i pływów & $\begin{array}{l}\text { Paliwa organiczne: węgiel kamienny i brunatny, ropa } \\
\text { i gaz ziemny }\end{array}$ \\
\cline { 1 - 1 } Energia promieniowania słonecznego & \\
\cline { 1 - 1 } Energia wiatru & \multirow{2}{*}{ Paliwa jądrowe: uran, tor, lit, hel } \\
\cline { 1 - 1 } Energia wody & \\
\cline { 1 - 2 } Energia geotermalna &
\end{tabular}

Tabela 1. Podział energii pierwotnej Źródło: opracowanie własne na podstawie B. Gerhard, M. Tomaszewski, Polityka energetyczna..., s. 44.

Natomiast energia finalna jest energią będącą przedmiotem zakupu w celu zaspokojenia potrzeb człowieka. Inaczej mówiąc jest to energia zużyta przez końcowego odbiorcę ${ }^{12}$. Jest to źródło energii przetworzonej, uzyskanej podczas procesu technologicznego w wyniku wykorzystania węgla, ropy, gazu, wiatru, wody i innych. Ilość energii elektrycznej, energii cieplnej i paliw płynnych daje możliwości dalszego rozwoju gospodarczego kraju oraz jest miarą już osiągniętego rozwoju ${ }^{13}$.

W latach 2003-2013 odnotowano wzrost całkowitego zużycia energii pierwotnej, który z 91 Mtoe (milion ton oleju ekwiwalentnego) wzrósł do 98 Mtoe w przeliczeniu na procenty jest to $0,7 \% \mathrm{w}$ skali roku. Natomiast spadek zużycia energii $\mathrm{w}$ tym okresie odnotowano w latach 2009 i 2012-2013. Średnioroczne tempo wzrostu zużycia energii finalnej wynosiło 1,4\% w latach 2003-2013. Przeliczając to na jednostki bezwzględne przyrost wyniósł 8 Mtoe. W tym przypadku również odnotowano spadek zużycia energii, który był w latach 2009, 2011-2013 ${ }^{14}$.

Polska energetyka jest skoncentrowana na wykorzystywanie zasobów naturalnych, gdzie źródłem energii pierwotnej jest węgiel kamienny i brunatny. Na poniższym wykresie 1 . zostało przedstawione zużycie fi-

12 H. Charun, Podstawy gospodarki energetycznej w zarysie, Tom 1, Wydawnictwo Uczelniane Politechniki Koszalińskiej, Koszalin, 2014, s. 56.

13 D. Niedziółka, Rynek energii w Polsce, Wydawnictwo Difin, Warszawa, 2010, s. 7.

14 Główny Urząd Statystyczny, Efektywność wykorzystania energii w latach 2003-2013. 
nalne surowców energetycznych w roku 2003 i 2013. W dużej mierze dominuje zużycie paliw ciekłych, które w obu latach miały 30\% udział. Energia $\mathrm{z}$ węgla również nie uległa zmianie, a jej udział wynosił $19 \%$. Podobnie było $\mathrm{z}$ udziałem gazu, który w obu latach odnotował 15\% udział. Największy wzrost udziału zużycia finalnego odnotowały pozostałe nośniki energii zyskując $10 \%$ udział. Natomiast znaczny spadek odnotowało ciepło schodząc do 10\%. Energia elektryczna uzyskała przyrost udziału o 1 p.p. osiągając tym 17\% zużycia energii finalnej.

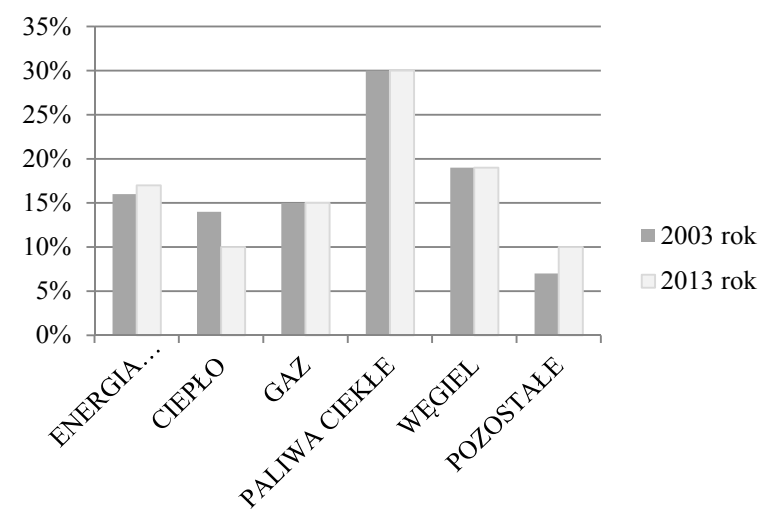

Wykres 1. Struktura finalnego zużycia energii w Polsce wg nośników Źródło: opracowanie własne na podstawie: GUS, Efektywność wykorzystania...

Na tle Unii Europejskiej Polska reprezentuje się bardzo dobrze, gdyż jest jednym z największych producentów energii pierwotnej w całej Unii Europejskiej (8,9\% w 2013 r.). Wśród państw członkowskich UE wyższe pozyskanie energii miały Wielka Brytania, Francja i Niemcy. Udział Polski w zużyciu energii jest niższy i wyniósł 5,9\% w 2013 roku. Według danych z 2014 roku 81\% energii elektrycznej pochodziło z węgla, a udział pozostałych nośników był niewielki. W innych państwach członkowskich produkcja energii elektrycznej jest bardziej zróżnicowana w stosowaniu nośników energii. Wyjątkiem jest Francja, w której dominuje energia z elektrowni atomowych ${ }^{15}$.

Istotne dla efektywności energetycznej jest też sprawdzenie poziomu energochłonności. Energochłonność pierwotna oznacza relacje całkowitego zużycia energii pierwotnej do PKB. W roku 2012 energochłonność pierwotna wynosiła 0,166 kgoe/euro05ppp i przewyższyła średnią europejską o 15\%. W latach 2000-2012 nastąpiła poprawa energochłonności w Polsce, była ponad dwa razy wyższa niż w UE. Natomiast energochłon-

15 Główny Urząd Statystyczny, Gospodarka paliwowo... 
ność finalna PKB oznacza relację zużycia energii finalnej do PKB. W tym przypadku różnica pomiędzy Polską, a średnią UE jest mniejsza i wynosiła 13\%. Tempo poprawy efektywności energetycznej w latach 2000-2012 w Polsce było niższe $\left(2,7 \%\right.$, ) a średnia europejska wynosiła $1,6 \% /$ rok $^{16}$.

\section{Działania mające na celu poprawę efektywności energetycznej}

Efektywność energetyczną można poprawić poprzez zastosowanie odpowiednich działań, do których można by zaliczyć przebudowę i remont budynków, izolację instalacji, ograniczenie przepływów mocy biernej, strat sieciowych w ciągach liniowych oraz modernizację urządzeń domowych, oświetlenia, sieci ciepłowniczych ${ }^{17}$. Natomiast Krajowy Plan Działań przewiduje inne środki, służące poprawie efektywności energetycznej. Są to środki horyzontalne, do których zalicza się między innym białe certyfikaty, kampanie informacyjno-edukacyjne oraz audyt efektywności energetycznej ${ }^{18}$.

Formalna nazwa białych certyfikatów to świadectwa efektywności energetycznej. Certyfikaty te przyczyniają się do zwiększenia oszczędności energii przez odbiorców końcowych i urządzenia potrzeb własnych oraz zmniejszenie strat energii elektrycznej, ciepła lub gazu ziemnego w przesyle lub dystrybucji. Białe certyfikaty są przyznawane przez Prezesa Urzędu Regulacji Energetyki przedsięwzięciom, które poprawiły efektywność energetyczną ${ }^{19}$. Jak wynika z ustawy, świadectwa efektywności energetycznej są prawami majątkowymi, które można zbyć. Można je uzyskać za przedsięwzięcia, które osiągnęły najwyższą efektywność ekonomiczną. Na podstawie przeprowadzonego przetargu wygrywa podmiot, który zaoferował największą oszczędność energii w relacji do uzyskanej wartości białego certyfikatu ${ }^{20}$.

Znacznie lepszym sposobem na zwrócenie uwagi społeczeństwa i pobudzenie ich świadomości jest stworzenie reklamy. Dlatego też wśród działań na rzecz poprawy efektywności energetycznej zostały zrealizowane kampanie informacyjno-edukacyjne. Najbardziej rozpowszechniona była kampania pod tytułem: „Wyłączamy prąd, włączamy oszczędzanie”. Akcję zainicjowało Ministerstwo Gospodarki koncentrując się na oszczę-

\footnotetext{
16 Główny Urząd Statystyczny, Efektywność wykorzystania...

17 Pakiet klimatyczno-energetyczny do 2020 roku, ec.europa.eu/clima/policies/strategies/2020/ index_pl.htm [dostęp online: 15.05.2016].

18 Ministerstwo Gospodarki, Ustawa z dnia 15 kwietnia 2011 o efektywności energetycznej.

19 www.bialecertyfikaty.com.pl/bialecertyfikaty [dostęp online: 17.05.2016].

20 Główny Urząd Statystyczny, Efektywność wykorzystania...
} 
dzaniu energii w gospodarstwach domowych. Aby jeszcze bardziej zwrócić uwagę widza $\mathrm{w}$ reklamie wzięły udział znane osoby, które zachęcały do oszczędzania energii poprzez proste codzienne czynności ${ }^{21}$.

Kolejnym istotnym działaniem dla systemu energetycznego ze względu na ponoszone koszty i osiągane korzyści jest przeprowadzanie audytu efektywności energetycznej. Jak definiuje Ustawa o efektywności energetycznej audyt efektywności energetycznej jest to zbiór dokumentów, w którym znajdują się:

- analizy zużycia energii,

- stan obiektu, urządzeń technicznych, instalacji,

- wykaz przedsięwzięć mających na celu poprawę efektywności energetycznej,

- informacje na temat opłacalności ekonomicznej,

- oraz możliwych oszczędnościach energii.

Jest przygotowywany na potrzebę uzyskania wsparcia w postaci białych certyfikatów ${ }^{22}$. Natomiast sam audyt energetyczny umożliwia rzeczywiste rozpoznanie zasobów pod względem działań proefektywnościowych oraz przyczynia się do ustalenia priorytetów w tym zakresie. Potwierdza uzyskane efekty energetyczne i ekologiczne zrealizowane przez działania służące efektywności. Jest działaniem, które obniża koszty funkcjonowania przedsiębiorstwa. Aby uzyskać świadectwo efektywności energetycznej konieczne jest przeprowadzenie audytu².

Mogłoby się wydawać, że działania naszego kraju w kierunku lepszej efektywności są realizowane na szeroką skale. Niestety mając na uwadze porównanie do działań podejmowanych przez kraje Unii Europejskiej wypadamy pod tym względem bardzo słabo, co zostało pokazane na wykresie 2 .

Na poniższym wykresie zostały porównane planowane i realizowane działania na rzecz poprawy efektywności energetycznej w Polsce i w krajach UE. Można stwierdzić, że Polska ma stosunkowo niewiele środków finansowych na tle Unii Europejskiej. W Polsce największy nacisk jest kładziony na sektor transportu ze względu na wykorzystywanie ropy, jako paliwa samochodowego, jak również na działania zmierzające ku zrównoważonemu transportowi.

\footnotetext{
Ibidem.

22 Ministerstwo Gospodarki, Ustawa z dnia...

23 www.bialecertyfikaty.com.pl/audyt-efektywnosci-energetycznej [dostęp online: 17.05.2016].
} 
UE-29 Polska

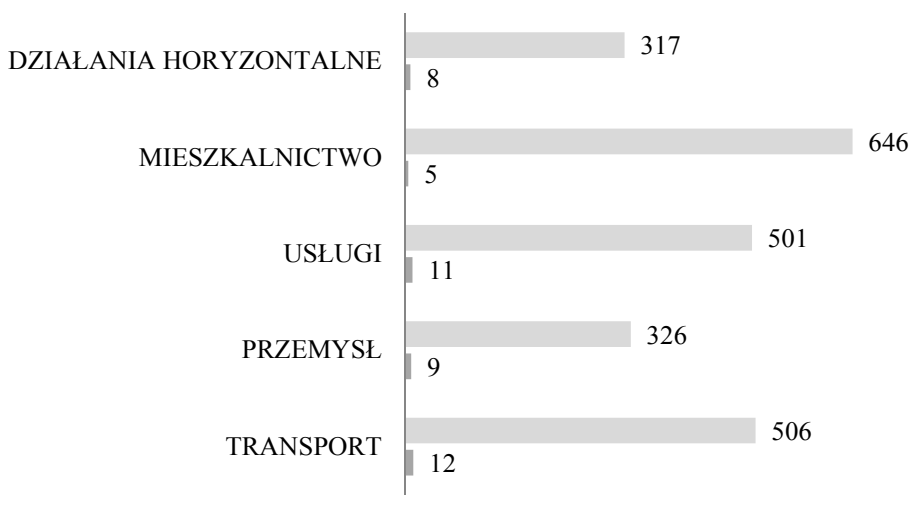

Wykres 2. Liczba działań w zakresie poprawy efektywności energetycznej w Polsce na tle Unii Europejskiej

Źródło: opracowanie własne na podstawie Główny Urząd Statystyczny, Efektywność wykorzystania..

Działania skupiające się na poprawie efektywności energetycznej $\mathrm{w}$ dużej mierze promują wykorzystywanie ciepła pochodzącego $\mathrm{z}$ kogeneracji i odnawialnych źródeł energii, jak również wykorzystanie systemów zarządzania energią i audytów energetycznych ${ }^{24}$.

Warto zauważyć, że przyjmowane działania nie są jedynymi, które można podjąć na rzecz poprawy efektywności energetycznej. Ważną rolę w poprawie oszczędności energii odgrywają właściciele gospodarstw domowych, którzy mają możliwość oszczędzania energii w godzinach szczytu, zakupu mniej energochłonnych urządzeń, czy też zastosowania takiego rodzaju technologii, które stanowić będą niezwykłą oszczędność energii cieplnej.

\section{Zrównoważona energetyka i bezpieczeństwo energetyczne}

Zaspokojenie potrzeb energetycznych społeczeństwa wpływa negatywnie na stan środowiska przyrodniczego. Ze względu na duże zanieczyszczenie środowiska zaczęto zwracać coraz większą uwagę na zużycie energii oraz na jej efektywność wykorzystania. W tym celu opracowano ideę zrównoważonego rozwoju energetycznego, która polega na gospo-

24 www.bialecertyfikaty.com.pl/efektywnosc-energetyczna [dostęp online: 17.05.2016]. 
darowaniu energią $\mathrm{w}$ taki sposób, by zapewnić dostęp do wystarczającej ilości energii nam i przyszłym pokoleniom oraz by nie wpływała negatywnie na środowisko. Zanieczyszczenia powstają przy produkcji energii oraz podczas zużywania tradycyjnych surowców energetycznych ${ }^{25}$.

Istotnym działaniem w obrębie gospodarki energetycznej jest zapewnienie jej bezpieczeństwa energetycznego. Podstawowe znaczenie dla bezpieczeństwa ma struktura zaopatrzenia gospodarki w energię pierwotną, zapotrzebowanie na energie, efektywność ekonomiczna i energetyczna gospodarki, świadomość społeczna, innowacyjność technologiczna ${ }^{26}$. Bezpieczeństwo energetyczne oznacza taki stan gospodarki, w którym zapotrzebowanie na paliwa i energię nie będzie zakłócone. W 65\% Polski bilans energetyczny stanowi ropa i gaz. Aby osiągnąć bezpieczeństwo energetyczne Polska musi być niezależna pod względem energetycznym i szukać nowych alternatywnych źródeł energii ${ }^{27}$.

Powyższe aspekty w pewnym sensie mają wpływ na efektywność wykorzystania surowców energetycznych. Istotne jest zrównoważone wykorzystywanie surowców ze względu na przyszłe pokolenia, jak i ich dostępność pozwalająca na wolność energetyczną.

\section{Podsumowanie}

Prognoza zasobów energetycznych szczególnie węgla kamiennego i brunatnego w Polsce wskazuje, że przy racjonalnym ich wykorzystaniu starczą one na ponad 150 lat. Natomiast pozostałe surowce, takie jak ropa naftowa czy gaz ziemny są już w dużej mierze importowane, na przykład z Rosji. Polityka energetyczna Unii Europejskiej nie reguluje kwestii związanych z uwarunkowaniem przestrzennym zasobów i zaopatrzenia w nośniki energii. Dlatego też Polska powinna jak najszybciej znaleźć optymalne rozwiązania dla połączenia gazu i energii elektrycznej z innymi krajami w ramach solidarności energetycznej krajów Unii Europejskiej. Zgodnie z polityką energetyczną, a także efektywnością energetyczną, w Polsce są realizowane działania, które uwzględniają posiadane zasoby energetyczne, a także technologie wytwarzania i przesyłu energii. Na tle Unii Europejskiej można zauważyć, że efektywność energetyczna Polski znacznie się poprawiła, jak również odnotowano wzrost energochłonności powyżej średniej europejskiej.

25 Instytut na rzecz zrównoważonego rozwoju, Zrównoważona energetyka, Warszawa, 2011, S. 12.

26 B. Gerhard, M. Tomaszewski, Polityka energetyczna..., s. 43.

27 P. Kwiatkiewicz, Bezpieczeństwo energetyczne-surowce kopalne vs alternatywne źródła energii, s. 293. 


\section{Bibliografia}

\section{Literatura książkowa}

Brzóska M., Gospodarka surowcami energetycznymi na świecie i w Polsce $w$ kontekście dyrektyw unijnych, [w] P. Kwiatkiewicz (red) Bezpieczeństwo energetyczne - surowce kopalne vs alternatywne źródła energii, Wydawnictwo Wyższej Szkoły Bezpieczeństwa, Poznań, 2013.

Charun H., Podstawy gospodarki energetycznej w zarysie, Tom 1, Wydawnictwo Uczelniane Politechniki Koszalińskiej, Koszalin, 2014

Gerhard B., Tomaszewski M., Polityka energetyczna i bezpieczeństwo energetyczne, Wydawnictwo Nowa Energia, Racibórz, 2009.

Niedziółka D., Rynek energii w Polsce, Wydawnictwo Difin, Warszawa, 2010.

Instytut na rzecz ekorozwoju, $Z$ energetyką przyjazną środowisku za pan brat - zrównoważone miasto, Wydawnictwo Wiatr, Warszawa, 2011.

\section{Dokumenty}

Ustawa z dnia 15 kwietnia 2011 r. o efektywno- Ministerstwo Gospodarki, Krajowy Plan Dziaści energetycznej, (Dz.U. 2011 nr 94 poz. $\quad$ łań dotyczący efektywności energetycznej $551, z$ późn. $Z m$.). dla Polski 2014, Warszawa 2014.

Główny Urząd Statystyczny, Efektywność wy- Ministerstwo Gospodarki, Polityka Energetyczkorzystania energii w latach 2003-2013, na Polski do 2030 roku, Warszawa, 10 listoWarszawa 2015. pada, 2009.

Główny Urząd Statystyczny, Gospodarka paliwowo-energetyczna w latach 2013 i 2014, Warszawa, 2015.

\section{Strony internetowe}

www.ec.europa.eu.pl www.bialecertyfikaty.com.pl 